\title{
Monitoring of Labour Mobility as a Way to Competitiveness
}

\section{Vnoučková Lucie}

\begin{abstract}
The current economic situation is forcing organisations to keep their best, talented employees, because employees are a critical and the most valuable asset. The paper reveals, based on the primary research, unsuitable practices of organisations in human resources and personnel relations and suggests improvements and recommendations how to keep knowledgeable employees. An induction method revealed main factors causing employee turnover (remuneration, future certainty, relationships, recognition, communication, corporate culture and expectations). Attributes of identified factors which influence organisational disaffection and fluctuation were searched and interpreted based on a quantitative survey. The paper describes inadequate behaviour inside organisations together with highlighting of the determinants which are the most common reason for a decision to leave. The aim is to point-out critical variables in order to lower disaffection and layoffs in organisations. It is essential for a modern knowledge-based organisation to be aware of the main causes and consequences of employee fluctuation to maintain competitiveness.
\end{abstract}

Key Words: Mobility, turnover, buman resources, disaffection, management, organisation

\section{INTRODUCTION}

There are several trends occurring within the employment scene that suggest organisations need to pay better attention to turnover and retention issues. It is important to note that employee turnover significantly affect overall financial performance (Bowes, 2010). Employee turnover is the level of movement of employees inside and outside the organisation (Reiß, 2008). Turnover has both positive and negative aspects, however, it is in the interest of organisations to eliminate its negative impacts and an excessive (negative) level of turnover that threatens knowledge continuity in organisations (Branham, 2005; Ertl, 2005; Reiß, 2008; Zahorsky, 2010) and is an undue burden for a organisation's budget and human resources, i.e. time dedicated to employee prospecting, advertisements, interviews, initial training, supervision, motivation, evaluation, familiarization with the new job, mentoring, coaching, substitution while the position is vacant (Armstrong, 2009; Bowes, 2010; Reiß, 2008). The aim of the article is therefore to describe, following the identification of reasons for employees' decisions to leave their job, individual problematic elements within the frame of personnel activities of the organisation and to formulate recommended procedures to eliminate these negative phenomena. 


\section{THEORETICAL BACKGROUND OF THE WORK}

Employee turnover can significantly affect the financial performance of organisation (Bowes, 2010). A general approach to calculate employee turnover cost is to use $50 \%$ to $200 \%$ of an employee's annual salary (CIPD, 2004; Ertl, 2005; Katcher, Snyder, 2007; Reiß, 2008; Zahorsky, 2010). Reducing employee turnover depends on the total work environment for employees (Heathfield, 2010). The organisations that achieve the most dramatic reductions in turnover and maintain those lower levels are usually the ones where the top executive or owner makes it a priority (Branham, 2000). But managers are not ready to change their convention in relation with disaffection or turnover of their subordinate staff (Brnaham, 2006, Katcher, Snyder, 2007). Majority of managers indicate remuneration as the main reason of employee turnover ( 80 - 98\%). Employees indicate contrary. 80 to $90 \%$ of employees leave their job position by different reasons, other than remuneration (Branham 2005, 2010; CIPD, 2004).

Heathfield, (2010) note that employee retention is a challenge since, particularly millennial employees, change jobs frequently. But Branham (2005), Katcher, Snyder, (2007), Kocianová (2010) and Pauknerová, (2006) have pointed out, that employees are missing future certainty. It leads to first impulse to think about leaving job position to remove this dissonance. Negative impacts on certainty have missing strategy, lack of communication and information about organisation future growth, unforeseen effects predominate in the organisation, lack of quality, ethics, resources, promotion and development (Bělohlávek, 2008; Horalíková, Zuzák, 2005; Katcher, Snyder, 2007; Kocianová, 2010). Employee-friendly organisations that value, empower, recognize, enable, provide feedback and fairly pay to their employees will not have a recruiting or an employee turnover problem (Heathfield, 2010), because interpersonal relationship and sense of belonging is one of the main human needs (Deiblová, 2005; Kocianová, 2010; Maslow, 1943; McClelland, 1987; McGregor, 2006; Vroom, 1990). Employees live most of the week in the organisation environment and good relationship with their co-workers and management of the firm is crucial for job satisfaction. Ability of organisation to handle with employees equal to managers and possibility to have time for personal life (part-time employment etc.) fosters employee loyalty (Branaham, 2005; Katcher, Snyder, 2007). Employees need is also to be recognized in their job positions. Role and position in organisation have significant impact also to personal life of employee (Deiblová, 2005; Kocianová, 2010).

In conclusion, most important retention recommendations are following (Bowes, 2010; Branham, 2000; Finnegan, 2010; Heathfield, 2010; Katcher, Snyder, 2007; Zahorsky, 2010):

- Good coaching and interaction between employee and supervisor (communication).

- Opportunity to learn new skills, recognition for a well done job (recognition).

- Good compensation and benefits package (remuneration).

- Challenging, rewarding, interesting work (corporate culture).

- Friendly co-workers (relationships).

- Talent and vision of organisation management team, strategic mission of the organisation (future certainty).

- Respectful treatment (expectations).

For employers it is very important to monitor the volume of employees who leave the organisation and how this factor influences the organisation. 
Bělohlávek (2008), Jenkins (2009) and Ramlall (2004) describe the causes of turnover as disharmony with internal motivation. If a need at a higher level of Maslow's pyramid of needs is not satisfied, an individual aims at satisfying a need at a lower hierarchical level. The most common case is that an employee's unfulfilled expectation in the area of self-development translates into the development of relationship needs (Bělohlávek, 2008; Mikuláštík, 2007). Should these be unsatisfactory as well, an employee leaves his/her job (unless conditions can be changed).

According to a study executed by Hackman and Oldham (1980) that concentrated on employees of educational institutions and scientists, six major factors determining turnover have been identified. These factors include the level of compensation and benefits, promotion and development, meaningfulness of work, a superior's style of management, relationships with colleagues and work safety. Pass (2005) in Anderson (2009) mentions the 3R system (Recognition, Respect, Relationships) as the main reason for employee satisfaction. Anderson (2009), Branham (2005) and Katcher and Snyder (2007) extend it by remuneration, suitable culture at the workplace, security (and safety) of work. Ramlall (2004) has divided motivational factors leading to employee satisfaction in their work position into satisfying basic motivational needs according to Maslow (1943), i.e. equal treatment, fulfilment of expectations and workplace concept. The outcome of the studies was a low correlation between dissatisfaction at the workplace leading to turnover and the level of compensation. On the contrary, organisations were recommended to concentrate on the improvement of employee qualifications, enhancement of competences and clear specification of the meaning of the content of the given position.

Turnover is an extreme case of dissatisfaction - demotivation that is characterised by one (or a combination) of the above-mentioned causes. If the basic working conditions expected by an employee are not met, the employee becomes frustrated (Deiblová, 2005; Kocianová, 2010; Bělohlávek, 2008). The gathered motivational energy remains unused.

\section{AIM AND METHODOLOGY}

The aim of the article is, based on the deduction and induction method using primary research, to point-out critical variables (causes of employee turnover) in order to lower disaffection and layoffs in organisations. Recommendations to eliminate negative employee turnover will be specified.

Taking into account the identified reasons of employee turnover, the article presents, based on a survey, problematic areas within the organisational environment that trigger employee turnover. Using a sample of respondents who left their jobs last year, the aim is to determine inadequate procedures in a sample of organisations as well as make proposals about how to eliminate unsuitable practices found using the background information from a quantitative survey.

The data for the evaluation of reasons for employees' leaving of their jobs has been collected in two successive quantitative surveys by means of questionnaire investigation. Both questionnaires were completed by 100 employees each (different respondents were chosen for the first and second questionnaire) who had already left their jobs. The method used for the collection of data in the first survey was an electronic questionnaire that automatically recorded and pre-categorised respondents' answers. The second, control questionnaire was based on the CATI method (computer-assisted telephone interviewing). The selection of a representative sample of employee 
population across sectors was carried out by a random selection of telephone numbers, which incorporates the advantages of multilevel random selection (Disman, 2008). The sample was selected solely for the purposes of the survey and included employees in the age category from 20 to 50 who left their job in the course of the past twelve months. Following an introduction, respondents were included in the survey provided they had satisfied the predefined conditions. Their answers were categorised according to identification questions that formed the first part of the questionnaire. In the first survey, the measurement was based on closed questions with one or several possible answer(s) that had been selected based on the study of literature, documents and other related surveys carried out by the following authors: Branham (2005), Hackman (1980), Meyer, Allen (2004) and Katcher and Snyder (2007). In the second survey a semantic differential was applied that permitted the identification of nuances in respondents' attitudes through the questionnaire. Respondents' reactions to target statements and their attitudes to the given matter were restricted by offering a set of several statements (Hayes, 1998). The extremes of the seven-point scale represented bipolar concepts of the evaluation dimension. Using a scale of 1 to 7 , respondents expressed their inclination towards one of the preset extreme statements or, provided it was not possible to favour either of the sides, selected a median, neutral value (the median value was characterised by number 4 ). The scale permitted not only the specification of respondents' attitudes, but also their intensity. The analysis was carried out using the Microsoft Excel 2007 and SPSS programmes. The conclusiveness of the outputs and relationships obtained were supported by the tools of descriptive statistics, the analysis of dispersion, parametric tests and correlation, and regression and determination were used to review the outcomes.

Using the method of induction, factors characterising the internal organisational causes of dissatisfaction of employees leaving their jobs were identified. These factors are as follows: remuneration, security, relationships, recognition, communication, culture and expectations. For reasons of provable clear understanding, the factors were structured as general, analogically to the survey carried out by Gosling, Rentfrow and Swann (2003), John, Naumann and Soto (2008) and Benet-Martinez and John (1998). The conclusiveness of the outcomes was supported by aggregation; by adding individual tested items the superordinate item and the whole were supported. Individual items of the construct sustaining final factors were tested separately and their reliability was added up in the whole. The conclusiveness of factors and their determinants was tested by means of a correlation analysis at the significance level of 0.01 . The outcomes indicate a direct and strong dependence between employee dissatisfaction with the identified factors and the decision to leave their work position. The factors were therefore used for further analyses.

\section{RESULTS}

The conclusiveness of the turnover-causing factors is shown in Tab. 1. A correlation analysis at the level of significance of 0.01 indicates direct, strong dependence between employee dissatisfaction with the stated factors and the leaving of a job. 
Tab. 1 - Relations between factors and employee mobility. Source: author's survey.

\begin{tabular}{|l|c|}
\hline Relation between factors and mobility & Pearson's coefficient \\
\hline Expectations - mobility & $0,95610^{* *}$ \\
\hline Culture - mobility & $0,99072^{* *}$ \\
\hline Certainty - mobility & $0,98788^{* *}$ \\
\hline Communication - mobility & $0,88209 * *$ \\
\hline Relationships - mobility & $0,92022^{* *}$ \\
\hline Recognition - mobility & $0,87689^{* *}$ \\
\hline Remuneration - mobility & $0,97052^{* *}$ \\
\hline
\end{tabular}

Organisational causes of employees' decision to leave are interwoven with personal and informal aspects, as shown in Tab. 2. The Table also illustrates the differences between reasons for turnover in small national and large multinational organisations. Positive relationships and their experiencing create favourable predispositions for the strengthening of motivation of employees to work well and perform better. Personal satisfaction is the main precondition of work satisfaction. Internally balanced employees perform better even despite worse conditions.

Tab. 2 - Factors affecting employee mobility. Source: author's survey.

\begin{tabular}{|l|c|c|c|}
\hline \multirow{2}{*}{ Factor } & \multicolumn{3}{|c|}{ \% mobility } \\
\cline { 2 - 4 } & Total & $\begin{array}{c}\text { Small } \\
\text { organisations }\end{array}$ & $\begin{array}{c}\text { Large } \\
\text { organisations }\end{array}$ \\
\hline Remuneration & 21 & 23 & 19 \\
\hline Certainty & 17 & 18 & 16 \\
\hline Relationships & 16 & 16 & 26 \\
\hline Recognition & 14 & 14 & 10 \\
\hline Communication & 14 & 10 & 16 \\
\hline Culture & 11 & 12 & 7 \\
\hline Expectations & 7 & 7 & 100 \\
\hline$\sum$ & 100 & 100 & 6 \\
\hline
\end{tabular}

For better identification of risk factors, shown below are specific determinants and levels of employee dissatisfaction when leaving the organisation. All the examined factors and partial influences having a crucial impact on the change of the negative turnover trend in organisations are described. The tables depict individual factors as perceived by employees. The relation to the communicated reasons for leaving will help one to understand the causes of dissatisfaction and will show partial criteria that need to be addressed in order to increase retention.

\subsection{Determinants of factor of expectations}

The opinions of employees as far as determinants influencing expectations are concerned are provided in Tab. 3. It illustrates that in their work employees most frequently use their qualifications. In total, however, $60 \%$ of employees mentioned the use of their qualifications (at least partial), on the contrary $28 \%$ of respondents did not exploit it at all. This high percentage suggests 
that in the process of recruitment employees should be selected in a better way in order to be able to use their potential knowledge. At present organisations have reserves in hiring employees for suitable positions as shown by the percentage of employees who do not use their skills (33\%) and qualifications (36\%). As the project initiation curve shows, independent work is not sufficiently encouraged. The shape of the curve corresponds to the still most common style of management in the Czech Republic, i.e. management of a directive nature, and to a relatively strict culture aimed at assigning tasks from above rather than a liberal kind of culture (also as shown in Table 4). The insufficient encouragement of independent work leads to employees' perception of the given work position as less attractive. Such employees are prone to change work positions in search of one where they would feel more satisfied and where their expectations would be met. Furthermore, it is possible to notice the correlation between the determinants of utilization of skills and the meeting of expectations at work. This trend demonstrates that if employees' skills can be utilized at work, their expectations are likely to be met.

Tab. 3 - Determinants of factor of expectations. Source: author's survey.

\begin{tabular}{|c|c|c|c|c|c|c|c|c|c|}
\hline Statement & Frequency & 1 & 2 & 3 & 4 & 5 & 6 & 7 & Statement \\
\hline \multirow{2}{*}{$\begin{array}{l}\text { Expected } \\
\text { job }\end{array}$} & absol. & 30 & 26 & 13 & 12 & 11 & 6 & 8 & \multirow{2}{*}{$\begin{array}{c}\text { Does not } \\
\text { meet expec- } \\
\text { tations }\end{array}$} \\
\hline & relativ. (\%) & 28,3 & 24,5 & 12,3 & 11,3 & 10,4 & 5,7 & 7,5 & \\
\hline \multirow{2}{*}{$\begin{array}{l}\text { Education } \\
\text { is used }\end{array}$} & absol. & 42 & 17 & 4 & 5 & 8 & 10 & 20 & \multirow{2}{*}{$\begin{array}{c}\text { Education } \\
\text { not used }\end{array}$} \\
\hline & relativ. (\%) & 39,6 & 16,0 & 3,8 & 4,7 & 7,5 & 9,4 & 18,9 & \\
\hline \multirow{2}{*}{$\begin{array}{l}\text { Qualifica- } \\
\text { tion is used }\end{array}$} & absol. & 29 & 24 & 15 & 3 & 11 & 11 & 13 & \multirow{2}{*}{$\begin{array}{c}\text { Qualifica- } \\
\text { tion not } \\
\text { used }\end{array}$} \\
\hline & relativ. $(\%)$ & 27,4 & 22,6 & 14,2 & 2,8 & 10,4 & 10,4 & 12,3 & \\
\hline \multirow{2}{*}{$\begin{array}{l}\text { Projects are } \\
\text { initiated }\end{array}$} & absol. & 13 & 13 & 18 & 19 & 10 & 7 & 14 & \multirow{2}{*}{$\begin{array}{l}\text { Projects are } \\
\text { given }\end{array}$} \\
\hline & relativ. (\%) & 13,8 & 13,8 & 19,1 & 20,2 & 10,6 & 7,4 & 14,9 & \\
\hline
\end{tabular}

Organisations have to find a compromise between the qualification requirements and employees' skills. It is necessary to place more emphasis on the selection of suitable candidates and to specify work position requirements in order to prevent differences. Employees have to be viewed as independently thinking individuals who are able to make decisions regarding their work. The feeling of independence and autonomy is associated with better recognition of work, a higher status and subjective position in the organisation, which is also one on the primary determinants of employee turnover.

\subsection{Determinants of factor of organisational culture}

Based on respondents' reactions, organisational culture has shown an inclination towards rigidity, strict checking, centralised decision-making and other phenomena, such as frequent overtime work. Tab. 4 implies that the majority of respondents perceive the style of management as directive $(60 \%)$. Moreover, respondents often mentioned assignment of tasks from above without further discussion about the problem ( $80 \%$ of respondents agree with this statement). $65 \%$ of respondents characterise culture as strict, less than $20 \%$ see the culture as liberal. The hiring of employees on acquaintance terms is used by one half of the organisations included in the survey, 
the second half applies objective evaluation or uses the services of recruitment agencies.

Respondents evaluate the quantity of work assigned to them as sufficient, and only $10 \%$ stated idle time in between the tasks and lower productivity. Almost all employees claim that they are able to manage the tasks assigned by the set deadline (92\%). This is connected with a lot of overtime work that employees are commonly asked to do. $73 \%$ of respondents mentioned they regularly worked overtime. This trend, however, is negative in terms of overburdening employees who are to work, as stipulated by law, only 40 hours per week (in some organisations only 37.5 hours). Overloading causes higher employee dissatisfaction and makes employees leave. Also, overtime work increases unemployment as work tasks that could be assigned to more labourers are carried out by one employee only.

Tab. 4 - Determinants of factor of organisational culture. Source: author's survey.

\begin{tabular}{|c|c|c|c|c|c|c|c|c|c|}
\hline Statement & Frequency & 1 & 2 & 3 & 4 & 5 & 6 & 7 & Statement \\
\hline \multirow{2}{*}{$\begin{array}{l}\text { Strict, strong } \\
\text { culture }\end{array}$} & absol. & 30 & 18 & 20 & 17 & 11 & 1 & 8 & \multirow{2}{*}{ Liberal culture } \\
\hline & relativ. $(\%)$ & 28,6 & 17,1 & 19,0 & 16,2 & 10,5 & 1,0 & 7,6 & \\
\hline \multirow{2}{*}{$\begin{array}{l}\text { Directive } \\
\text { decision- } \\
\text { making }\end{array}$} & absol. & 29 & 21 & 9 & 7 & 9 & 15 & 13 & \multirow{2}{*}{$\begin{array}{c}\text { Participative } \\
\text { decision-mak- } \\
\text { ing }\end{array}$} \\
\hline & relativ. (\%) & 28,2 & 20,4 & 8,7 & 6,8 & 8,7 & 14,6 & 12,6 & \\
\hline \multirow{2}{*}{$\begin{array}{l}\text { Tasks are } \\
\text { given }\end{array}$} & absol. & 56 & 23 & 8 & 6 & 4 & 4 & 5 & \multirow{2}{*}{$\begin{array}{c}\text { Tasks are dis- } \\
\text { cussed }\end{array}$} \\
\hline & relativ. $(\%)$ & 52,8 & 21,7 & 7,5 & 5,7 & 3,8 & 3,8 & 4,7 & \\
\hline \multirow{2}{*}{ Overtime } & absol. & 50 & 15 & 11 & 4 & 5 & 7 & 13 & \multirow{2}{*}{$\begin{array}{c}\text { Regular time of } \\
\text { work }\end{array}$} \\
\hline & relativ. $(\%)$ & 47,6 & 14,3 & 10,5 & 3,8 & 4,8 & 6,7 & 12,4 & \\
\hline \multirow{2}{*}{$\begin{array}{l}\text { Work suf- } \\
\text { ficiency }\end{array}$} & absol. & 59 & 23 & 6 & 6 & 4 & 2 & 5 & \multirow{2}{*}{ Boredom } \\
\hline & relativ. $(\%)$ & 56,2 & 21,9 & 5,7 & 5,7 & 3,8 & 1,9 & 4,8 & \\
\hline \multirow{2}{*}{$\begin{array}{l}\text { Tasks filled } \\
\text { on time }\end{array}$} & absol. & 49 & 32 & 14 & 4 & 2 & 1 & 2 & \multirow{2}{*}{$\begin{array}{c}\text { Terms are not } \\
\text { prosecuted }\end{array}$} \\
\hline & relativ. $(\%)$ & 47,1 & 30,8 & 13,5 & 3,8 & 1,9 & 1,0 & 1,9 & \\
\hline \multirow{2}{*}{$\begin{array}{l}\text { Recruitment } \\
\text { of familiarity }\end{array}$} & absol. & 19 & 13 & 11 & 10 & 1 & 13 & 29 & \multirow{2}{*}{$\begin{array}{l}\text { Objective } \\
\text { recruitment }\end{array}$} \\
\hline & relativ. $(\%)$ & 19,8 & 13,5 & 11,5 & 10,4 & 1,0 & 13,5 & 30,2 & \\
\hline
\end{tabular}

Furthermore, organisations should pay attention to the style of management favoured by employees. The survey reveals that the authoritative style of management prevails. Not all employees find this style of work assignment, communication and monitoring the most appropriate. It comes out of the trend of giving orders and preventing individual work and task solving introduced before 1989 is still applied. Since then, however, the management of people and their self-development has gone through a number of changes, and the new generation has been raised in a different way and organisations have to adjust to these changes if they wish to eliminate employee outflow.

\subsection{Determinants of factor of remuneration}

The lowest level of employee satisfaction was expressed with respect to remuneration. Tab. 5 is showing a growing tendency on the side of negative statements and dissatisfaction with partial attributes, although other factors have not proven so critical. Conditions in the CR are problematic 
in particular with respect to benefits that are either not provided at all $(50 \%)$ or if provided, they are not suitable (61\%). Organisations should therefore consider the introduction of benefits for their employees. Unsuitable benefits result in greater dissatisfaction than if not provided at all and classical forms of remuneration, such as base pay and bonuses, are preferred as employees feel that the money they have earned and that should be paid to them is wasted on useless benefits they are not interested in. The most frequent shortcomings of benefit systems are their non-transparency, high expectations arising from the excessive volume of benefits provided before the crisis, their inadequacy with respect to employee needs and in particular poor "PR" with respect to benefit provision. Benefits should also reflect employee lifecycle and take into consideration their needs and preferences.

The decrease in organisations' income resulting from the financial crisis has led to the lowering of remuneration and bonuses, which employees are reluctant to accept. This increases demotivation and worsens performance, which in turn means an even greater decrease of a organisation's performance and further reduction of remuneration and bonuses. Only $42 \%$ of respondents think their remuneration is motivating, on the contrary, $54 \%$ of them see it as demotivating. The demotivating nature of remuneration is backed by employees' opinion that there is no correlation between remuneration and performance. $47 \%$ of employees feel like this. Only $40 \%$ stated that there was a relation between performance and remuneration. $40 \%$ of employees said the remuneration was adequate. Half of them, on the other hand, think that the remuneration is unfair, some employees are favoured and receive higher remuneration than they are entitled to based on their performance and vice versa, the remuneration of some is below average if we take into consideration their position, conduct and performance.

Tab. 5 - Determinants of factor of remuneration. Source: author's survey.

\begin{tabular}{|c|c|c|c|c|c|c|c|c|c|}
\hline Statement & Frequency & 1 & 2 & 3 & 4 & 5 & 6 & 7 & Statement \\
\hline \multirow{2}{*}{ Motivating } & absol. & 21 & 11 & 13 & 4 & 12 & 13 & 32 & \multirow{2}{*}{ Demotivating } \\
\hline & relativ. (\%) & 19,8 & 10,4 & 12,3 & 3,8 & 11,3 & 12,3 & 30,2 & \\
\hline \multirow{2}{*}{ Adequate } & absol. & 20 & 12 & 11 & 11 & 14 & 13 & 25 & \multirow{2}{*}{ Inadequate } \\
\hline & relativ. $(\%)$ & 18,9 & 11,3 & 10,4 & 10,4 & 13,2 & 12,3 & 23,6 & \\
\hline \multirow{2}{*}{ Benefits } & absol. & 33 & 4 & 10 & 4 & 3 & 5 & 47 & \multirow{2}{*}{ No benefits } \\
\hline & relativ. $(\%)$ & 31,1 & 3,8 & 9,4 & 3,8 & 2,8 & 4,7 & 44,3 & \\
\hline \multirow{2}{*}{$\begin{array}{l}\text { Suitable } \\
\text { benefits }\end{array}$} & absol. & 17 & 11 & 6 & 7 & 6 & 6 & 52 & \multirow{2}{*}{$\begin{array}{c}\text { Unsuitable } \\
\text { benefits }\end{array}$} \\
\hline & relativ. (\%) & 16,2 & 10,5 & 5,7 & 6,7 & 5,7 & 5,7 & 49,5 & \\
\hline \multirow{2}{*}{$\begin{array}{l}\text { Equal to per- } \\
\text { formance }\end{array}$} & absol. & 17 & 12 & 13 & 14 & 17 & 15 & 17 & \multirow{2}{*}{$\begin{array}{l}\text { No link to } \\
\text { performance }\end{array}$} \\
\hline & relativ. $(\%)$ & 16,2 & 11,4 & 12,4 & 13,3 & 16,2 & 14,3 & 16,2 & \\
\hline
\end{tabular}

In order to decrease turnover, it is therefore necessary to focus on the elimination of benefits that are not used on larger grounds and to keep only those that employees show interest in the long run. Furthermore, it is necessary to correlate remuneration and performance and introduce fair remuneration. 


\subsection{Determinants of factor of relationships}

As far as relationships are concerned, employees feel that relationships between "peers" are the least conflicting and the most appropriate. $80 \%$ of employees said they found the relationships among colleagues satisfactory. Similarly, the major part of employees also viewed teamwork positively $(71 \%)$. A total of $19 \%$ of respondents feel that teams are not well set up. This is where there is space for possible intervention, in particular in large organisations where relationships are critical to maintaining a low level of turnover.

Determinants motivating teams, relationships between different management levels and equality in relationships and positions are problematic. All three determinants oscillate around the value of $15 \%$ both for agreement and disagreement. The trend of dissatisfaction with management was expressed in reactions of employees who described the management as authoritative where orders are given from above, there is a strict culture and there is no space for compromises or participation in the management. This is where it is essential to improve the level of satisfaction in relationships in order to maintain employee retention. Employees need to experience equality of positions, appreciation and the feeling of participative achievement of goals. On the whole, $42 \%$ of respondents characterise teams as motivating, however, the same percentage see them as demotivating. Similar applies to equal treatment. $44 \%$ of employees consider the treatment to be fair while $40 \%$ think it is unfair and feel there is an inclination to the formation of cliques and favouritism. The most positive outcomes have been recorded in relationships between organisational levels, where positive answers were given by $53 \%$ of employees and negative by $27 \%$.

Tab. 6 - Determinants of factor of relationships. Source: author's survey.

\begin{tabular}{|c|c|c|c|c|c|c|c|c|c|}
\hline Statement & Frequency & 1 & 2 & 3 & 4 & 5 & 6 & 7 & Statement \\
\hline \multirow{2}{*}{$\begin{array}{l}\text { Quality rela- } \\
\text { tionships }\end{array}$} & absol. & 47 & 20 & 16 & 8 & 7 & 5 & 2 & \multirow{2}{*}{$\begin{array}{c}\text { No collegi- } \\
\text { ality }\end{array}$} \\
\hline & relativ. (\%) & 44,8 & 19,0 & 15,2 & 7,6 & 6,7 & 4,8 & 1,9 & \\
\hline \multirow{2}{*}{$\begin{array}{l}\text { Good team } \\
\text { relationships }\end{array}$} & absol. & 32 & 28 & 15 & 10 & 7 & 9 & 5 & \multirow{2}{*}{$\begin{array}{c}\text { Inappropriate } \\
\text { team mem- } \\
\text { bers }\end{array}$} \\
\hline & relativ. $(\%)$ & 30,2 & 26,4 & 14,2 & 9,4 & 6,6 & 8,5 & 4,7 & \\
\hline \multirow{2}{*}{$\begin{array}{l}\text { Relation. } \\
\text { persist beyond } \\
\text { org. }\end{array}$} & absol. & 35 & 21 & 10 & 7 & 7 & 5 & 20 & \multirow{2}{*}{$\begin{array}{l}\text { Only work } \\
\text { relations }\end{array}$} \\
\hline & relativ. $(\%)$ & 33,3 & 20,0 & 9,5 & 6,7 & 6,7 & 4,8 & 19,0 & \\
\hline \multirow{2}{*}{$\begin{array}{l}\text { Good relation. } \\
\text { among hier. } \\
\text { levels }\end{array}$} & absol. & 19 & 24 & 14 & 20 & 9 & 8 & 12 & \multirow{2}{*}{$\begin{array}{c}\text { Formal or no } \\
\text { contact }\end{array}$} \\
\hline & relativ. $(\%)$ & 17,9 & 22,6 & 13,2 & 18,9 & 8,5 & 7,5 & 11,3 & \\
\hline \multirow{2}{*}{$\begin{array}{l}\text { Motivating } \\
\text { collective }\end{array}$} & absol. & 13 & 20 & 12 & 16 & 10 & 20 & 15 & \multirow{2}{*}{$\begin{array}{l}\text { Conflict low- } \\
\text { ers perform- } \\
\text { ance }\end{array}$} \\
\hline & relativ. (\%) & 12,3 & 18,9 & 11,3 & 15,1 & 9,4 & 18,9 & 14,2 & \\
\hline \multirow{2}{*}{ Equality } & absol. & 20 & 13 & 11 & 17 & 9 & 17 & 14 & \multirow{2}{*}{ Favouritism } \\
\hline & relativ. $(\%)$ & 19,8 & 12,9 & 10,9 & 16,8 & 8,9 & 16,8 & 13,9 & \\
\hline
\end{tabular}

In the course of the working process $63 \%$ of employees also become friends as they are in contact also outside working hours. Outside-organisation relationships are also good for the 
organisation as employees who are friends have a lower tendency to leave the organisation as they would also have to abandon their friends from work and their mutual contacts would no longer be as close and frequent (contacts after the termination of an employment contract are often undesirable due to the transfer of internal information and secrets). Therefore it is recommended to encourage friendships at the workplace. In connection with this determinant, extreme values have been identified also in the opposite direction where $19 \%$ of employees expressed a strict disagreement and described their relations with colleagues to be purely of a business nature (as shown by a significant diversion of Tab. 6, with respect to the determinant relationships that last also outside organisations). This extreme can be explained by a large number of work positions that are based solely on formal contacts (see Tab. 4) and solely on vertical (top-down) communication (see Tab. 9).

\subsection{Determinants of factor of recognition}

Tab. 7 as a whole demonstrates a decreasing tendency of dissatisfaction with partial determinants of the recognition factor; a strong diversion can be seen for the ideal work position determinant. The majority of employees $(80 \%)$ do not find their current position ideal and are searching for a different one. This determinant can be viewed as a result of partial dissatisfaction with other factors.

Recognition factor determinants - development as part of work, work being a challenge and the feeling of fulfilment - show a similar trend, more than half of employees are satisfied (for all three attributes the level of satisfaction is around $60 \%$ ) with the offered opportunities for education, development and fulfilment. Again, around 28\% of employees (27 - 29\%) hold an opposite opinion. These employees claim that they do not have a possibility of development in their position, that their work is monotonous, does not bring them satisfaction and that they have a feeling of uselessness and stagnation. The segment of dissatisfied employees is backed by the development of the possibility of promotion determinant. Similarly as for the ideal work determinant, as shown in Tab. 7 , it is stated reversibly compared to the trend. $57 \%$ of employees in the organisation have no possibility of promotion to a higher position. Employees realise this and if they lack opportunity of development and education, they are frustrated, dissatisfied and tend to think about leaving their current work. These tendencies have to be prevented. For some organisations (in particular small ones) it is impossible to ensure promotion to higher positions, however, they can concentrate on satisfying their employees by giving clear sense to their work, opportunity for assuming new tasks, changing of work positions, rotation and broadening and deepening of knowledge connected with their work. This is a way to motivate employees internally and strengthen their feeling of fulfilment.

Tab. 7 - Determinants of factor of recognition. Source: author's survey.

\begin{tabular}{|l|l|c|c|c|c|c|c|c|c|}
\hline Statement & Frequency & $\mathbf{1}$ & $\mathbf{2}$ & $\mathbf{3}$ & $\mathbf{4}$ & $\mathbf{5}$ & $\mathbf{6}$ & $\mathbf{7}$ & Statement \\
\hline \multirow{2}{*}{$\begin{array}{l}\text { Prestigious } \\
\text { position }\end{array}$} & absol. & 18 & 18 & 17 & 18 & 10 & 13 & 12 & Average posi- \\
\cline { 2 - 11 } & relativ. (\%) & 17,0 & 17,0 & 16,0 & 17,0 & 9,4 & 12,3 & 11,3 & tion \\
\hline \multirow{2}{*}{$\begin{array}{l}\text { Work is chal- } \\
\text { lenging }\end{array}$} & absol. & 29 & 19 & 16 & 13 & 12 & 12 & 4 & Stagnation \\
\cline { 2 - 10 } & relativ. (\%) & 27,6 & 18,1 & 15,2 & 12,4 & 11,4 & 11,4 & 3,8 & \\
\hline
\end{tabular}




\begin{tabular}{|c|c|c|c|c|c|c|c|c|c|}
\hline \multirow{2}{*}{$\begin{array}{l}\text { Possibil- } \\
\text { ity to grow, } \\
\text { promotion }\end{array}$} & absol. & 8 & 16 & 16 & 5 & 8 & 23 & 28 & \multirow{2}{*}{$\begin{array}{c}\text { No possibility } \\
\text { of develop- } \\
\text { ment }\end{array}$} \\
\hline & relativ. (\%) & 7,7 & 15,4 & 15,4 & 4,8 & 7,7 & 22,1 & 26,9 & \\
\hline \multirow{2}{*}{ Fulfilment } & absol. & 26 & 21 & 12 & 16 & 12 & 12 & 7 & \multirow{2}{*}{$\begin{array}{c}\text { Feeling of un- } \\
\text { importance }\end{array}$} \\
\hline & relativ. $(\%)$ & 24,5 & 19,8 & 11,3 & 15,1 & 11,3 & 11,3 & 6,6 & \\
\hline \multirow{2}{*}{$\begin{array}{l}\text { Develop- } \\
\text { ment as part } \\
\text { of work }\end{array}$} & absol. & 34 & 18 & 15 & 10 & 5 & 8 & 18 & \multirow{2}{*}{$\begin{array}{c}\text { No possibility } \\
\text { of education, } \\
\text { growth }\end{array}$} \\
\hline & relativ. (\%) & 31,5 & 16,7 & 13,9 & 9,3 & 4,6 & 7,4 & 16,7 & \\
\hline \multirow{2}{*}{$\begin{array}{l}\text { Ideal self-as- } \\
\text { sertion }\end{array}$} & absol. & 7 & 2 & 4 & 8 & 8 & 25 & 52 & \multirow{2}{*}{$\begin{array}{c}\text { Searching for } \\
\text { another job }\end{array}$} \\
\hline & relativ. (\%) & 6,6 & 1,9 & 3,8 & 7,5 & 7,5 & 23,6 & 49,1 & \\
\hline
\end{tabular}

In practice, these possibilities of work enhancement are rare as illustrated by the "development is a part of work" determinant. The determinant shows a significant increase in negative opinions of Tab. 7. A total of $29 \%$ of employees state that their organisation does not provide opportunities for further education and development.

\subsection{Determinants of factor of certainty}

Tab. 8 indicates similar development for all determinants. The majority of employees think their organisations behave ethically $(58 \%)$ and create values for society $(65 \%)$; the volume of work available and the number of projects processed (63\%) give them a feeling of security and they also feel that their organisation tends to grow $(61 \%)$. The factor of certainty thus does not seem to be a risk factor. It is, however, necessary to take notice of a significant deviation of all determinants of Tab. 8. A large number of respondents are convinced of the opposite (around $26 \%$ and up to $31 \%$ as far as the tendency to grow is concerned). A quarter to one third of employees is not an insignificant figure for an organisation, should the organisation lose them. Therefore it is necessary to inform employees about the situation in the organisation and about its planned development in order to eliminate the tendency to spread catastrophic scenarios and thus the feeling of insecurity of employees who subsequently deal with the situation by abandoning the "sinking ship". If information is not sufficiently communicated or even kept secret, employees tend to believe in a worse scenario.

Tab. 8 - Determinants of factor of certainty. Source: author's survey.

\begin{tabular}{|c|c|c|c|c|c|c|c|c|c|}
\hline Statement & Frequency & 1 & 2 & 3 & 4 & 5 & 6 & 7 & Statement \\
\hline \multirow{2}{*}{$\begin{array}{l}\text { Ethical or- } \\
\text { ganisation }\end{array}$} & absol. & 25 & 17 & 14 & 14 & 4 & 7 & 15 & \multirow{2}{*}{$\begin{array}{c}\text { No emphasis } \\
\text { on ethic }\end{array}$} \\
\hline & relativ. $(\%)$ & 26,0 & 17,7 & 14,6 & 14,6 & 4,2 & 7,3 & 15,6 & \\
\hline \multirow{2}{*}{ Social values } & absol. & 25 & 20 & 21 & 15 & 4 & 8 & 9 & \multirow{2}{*}{$\begin{array}{l}\text { Values only } \\
\text { for owners }\end{array}$} \\
\hline & relativ. $(\%)$ & 24,5 & 19,6 & 20,6 & 14,7 & 3,9 & 7,8 & 8,8 & \\
\hline \multirow{2}{*}{$\begin{array}{l}\text { High number } \\
\text { of projects }\end{array}$} & absol. & 18 & 26 & 14 & 10 & 5 & 9 & 10 & \multirow{2}{*}{$\begin{array}{l}\text { Uncertain } \\
\text { projects }\end{array}$} \\
\hline & relativ. $(\%)$ & 19,6 & 28,3 & 15,2 & 10,9 & 5,4 & 9,8 & 10,9 & \\
\hline \multirow{2}{*}{$\begin{array}{l}\text { Tendency to } \\
\text { grow }\end{array}$} & absol. & 31 & 23 & 10 & 8 & 7 & 10 & 16 & \multirow{2}{*}{$\begin{array}{l}\text { Stagnation, } \\
\text { attenuation }\end{array}$} \\
\hline & relativ. $(\%)$ & 29,5 & 21,9 & 9,5 & 7,6 & 6,7 & 9,5 & 15,2 & \\
\hline
\end{tabular}




\subsection{Determinants of factor of communication}

Tab. 9, depicting how employees perceive organisational communication, is very inconsistent. As shown in Tab. 3, employees characterize communication in organisations as formal (53\%); only $27 \%$ of employees find it informal. This is almost alarming if we take into account the fact that $63 \%$ of employees have established friendly relations with their colleagues. The rest of the communication is in the majority of cases formal.

Tab. 9 - Determinants of factor of communication. Source: author's survey

\begin{tabular}{|c|c|c|c|c|c|c|c|c|c|}
\hline Statement & Frequency & 1 & 2 & 3 & 4 & 5 & 6 & 7 & Statement \\
\hline \multirow{2}{*}{ Informal } & absol. & 17 & 7 & 5 & 20 & 18 & 15 & 23 & \multirow{2}{*}{ Formal } \\
\hline & relativ. $(\%)$ & 16,2 & 6,7 & 4,8 & 19,0 & 17,1 & 14,3 & 21,9 & \\
\hline \multirow{2}{*}{ Open } & absol. & 32 & 16 & 16 & 12 & 13 & 7 & 10 & \multirow{2}{*}{ Closed } \\
\hline & relativ. $(\%)$ & 30,2 & 15,1 & 15,1 & 11,3 & 12,3 & 6,6 & 9,4 & \\
\hline \multirow{2}{*}{ Top-down } & absol. & 36 & 21 & 17 & 15 & 4 & 8 & 2 & \multirow{2}{*}{ Bottom-up } \\
\hline & relativ. $(\%)$ & 35,0 & 20,4 & 16,5 & 14,6 & 3,9 & 7,8 & 1,9 & \\
\hline \multirow{2}{*}{ Oral } & absol. & 32 & 14 & 8 & 20 & 12 & 11 & 8 & \multirow{2}{*}{ Written } \\
\hline & relativ. $(\%)$ & 30,5 & 13,3 & 7,6 & 19,0 & 11,4 & 10,5 & 7,6 & \\
\hline \multirow{2}{*}{ Shared } & absol. & 19 & 17 & 12 & 15 & 10 & 14 & 19 & \multirow{2}{*}{ Directive } \\
\hline & relativ. $(\%)$ & 17,9 & 16,0 & 11,3 & 14,2 & 9,4 & 13,2 & 17,9 & \\
\hline \multirow{2}{*}{ Supporting } & absol. & 17 & 21 & 18 & 9 & 9 & 6 & 25 & \multirow{2}{*}{ Criticizing } \\
\hline & relativ. (\%) & 16,2 & 20,0 & 17,1 & 8,6 & 8,6 & 5,7 & 23,8 & \\
\hline \multirow{2}{*}{$\begin{array}{l}\text { Free deci- } \\
\text { sion-making }\end{array}$} & absol. & 23 & 15 & 18 & 7 & 6 & 14 & 23 & \multirow{2}{*}{ No choice } \\
\hline & relativ. $(\%)$ & 21,7 & 14,2 & 17,0 & 6,6 & 5,7 & 13,2 & 21,7 & \\
\hline
\end{tabular}

The formal style of communication also determines the prevailing direction of communication. According to respondents' answers, downward communication, i.e. assigning tasks without further discussion (as already shown in Tab. 3), prevails (72\%) in organisations. Less than $14 \%$ of employees see other possible directions of communication and discussion. The related trend supporting the role of communication in fulfilling assignments indicates only a slightly above average consent. Only $53 \%$ of employees find the way of organisational communication supportive while a rather high percentage (38\%) feels it is more about critique and limitation. As can be seen on the line of determinant of supporting communication, in Tab. 9 a high increase in dissatisfaction is evident with $24 \%$ of employees stating that they have experienced extremely unsuitable communication techniques. This point is alarming; an efficient development of an organisation requires that this unsuitable way of communication be eliminated. Communication is a problematic factor in particular in large organisations and this demonstrates the possible cause.

Determinant of open communication has a negative trend; employees favour a rather unrestricted way of sharing information $(60 \%)$ without any unnecessary concealing thereof. $28 \%$ of employees have experienced this. Employees have a less positive perception of information sharing. Flawless communication or communication with minor difficulties works in $45 \%$ of cases, problems, poor communication or no communication is a common reality in $41 \%$ of organisations. The difference between both extremes is almost meaningless; therefore organisations should pay more attention in particular to this attribute. Similarly, there is a small difference in 
perceiving the freedom of decision-making. 53\% of employees have (at least partial) possibility of independent decision-making when performing their work, however, $41 \%$ of employees are confined to strict adherence to prescribed procedures. Again, it is possible to notice a significant increase of negative experience on the curve of freedom of decision-making in Tab. 9 where $22 \%$ of employees selected the extreme statement as regards the impossibility of independent decision-making.

\section{DISCUSSION}

As personnel theory states, employee retention is a challenge because millennial employees change jobs frequently. But still, organisations should take care about keeping such as talents, knowledge and key workers. In Czech organisations, however, unsuitable practices were discovered. In order to keep employees, the attention should be paid to elimination of current problematic behaviour.

According to a previous study executed by Hackman and Oldham (1980), six major factors determining turnover have been identified. These factors include remuneration, recognition, meaningfulness of work, a superior's style of management, relationships and work safety. Pass (2005) in Anderson (2009) mentions the 3R system (Recognition, Respect, Relationships). The study conducted in the Czech Republic revealed seven main factors determining disaffection and may lead to layoffs. Those are expectations, relationship, recognition, remuneration, future certainty, communication and culture.

Employees, according to theory are missing interpersonal relationship and sense of belonging is one of the main human needs (Deiblová, 2005; Kocianová, 2010; Maslow, 1943; McClelland, 1987; McGregor, 2006; Vroom, 1990). According to theoretic background, the results of the survey specified that two thirds of respondents had problem with directive leadership, strict culture and worked overtime. Also, 20\% stated problems within set up of the teams; only half of respondents talked about team members as helpful, motivating. The other half stated the contrary. Additionally, results of the survey shows that in $40 \%$ the treatment to employees is unfair, with favoritism of some employees. Also, the level of communication is sometimes inappropriate. Only $53 \%$ of respondents talked about supportive communication. On the other hand, 38\% feel it is more about critique; $24 \%$ stated experience with extremely unsuitable communication. This leaded to dissatisfaction of employees and may lead to turnover.

Results revealed also problems with expectations and recognition. One third of respondents never used their skills, education and qualification. The same number of employees stated that their work is monotonous, they experience stagnation, with no possibility to grow, no possibility for further education or development. $57 \%$ of respondents stated no possibility to promotion or to future grow. As Bělohlávek (2008) and Mikuláštík (2007) stated, unfulfilled expectation in the area of self-development translates into the development of relationship needs. But, as mentioned above, there are still some problems with relationships and thus employees tend to leave the organisation.

In Czech organisations, also problematic remuneration was found. Only $42 \%$ of employees found their salary as equal, with relation to their performance. More than $50 \%$ of employees have problems with benefits, $62 \%$ of them stated, that benefits are not suitable. 
Therefore, results of primary research allow us to formulate several recommendations. Firstly, more attention should be paid to recruitment. Organisations, in order to keep their employees, have to find a compromise between the qualification requirements and employees' skills. It is necessary to place more emphasis on the selection of suitable candidates and to specify work position requirements in order to prevent differences.

Furthermore, organisations should pay attention to the style of management favoured by employees. The survey reveals that the authoritative style of management prevails. Not all employees find this style of work assignment, communication and monitoring the most appropriate. The new generation has been raised in a different way and organisations have to adjust to these changes if they wish to eliminate employee outflow.

Thirdly, in order to decrease turnover, it is necessary to focus on the elimination of benefits that are not used on larger grounds and to keep only those that employees show interest in the long run. Furthermore, it is necessary to correlate remuneration and performance and introduce fair remuneration.

Fourthly, it is recommended to encourage friendships at the workplace. Employees who have friends at the workplace have a lower tendency to leave the organisation as they would also have to abandon their friends from work and their mutual contacts would no longer be as close and frequent.

Fifthly, a way to motivate employees internally and strengthen their feeling of fulfilment is necessary through ensuring promotion to higher positions or, if this is not possible, however, organisations can concentrate on satisfying their employees by giving clear sense to their work, opportunity for assuming new tasks, changing of work positions, rotation and broadening and deepening of knowledge connected with their work.

Sixthly, it is necessary to inform employees about the situation in the organisation and about its planned development in order to eliminate the tendency to spread catastrophic scenarios and thus the feeling of insecurity of employees who subsequently deal with the situation by abandoning the "sinking ship".

And finally, open and shared communication is the key to success.

\section{CONCLUSIONS}

The survey covering a sample of randomly selected respondents has confirmed the factors determining employee turnover. Seven internal organisational factors have been identified (remuneration, certainty, relationships, recognition, communication, culture and expectations). The correlation analysis indicates a direct and strong dependence between employee dissatisfaction with the above-mentioned factors and leaving of a work position. Employee satisfaction in an organisation is subjectively measured in relation to personal and informal aspects. The most common reasons for leaving are, according to the data collected, remuneration (21\%) and an insufficient level of future security $(17 \%)$. Both of these factors form part of a construct falling under the category of an employee's personal expectations. These were followed by factors associated with relationships at the workplace $(16 \%)$ that also indicate an emphasis on an informal and personal level. The dissatisfaction with recognition at the workplace (14\%) has confirmed 
the concept. The style and state of communication within organisations (14\%) came after followed by the type of culture prevailing at the workplace $(11 \%)$.

The outcomes of the analysis of individual factors determining turnover brought an insight into problematic situations examined in a sample of population. Respondents' dissatisfaction grew significantly in relation to management of a directive nature (by 60\%) and a culture that is rather rigid and focused on assignment of tasks from the above (80\%) as insufficient support of independent work leads to the degradation of the value of the working position for an employee in terms of its attractiveness. The sense of independence and autonomy improved the perception of work recognition, status and a subjectively perceived position in an organisation. Unsuitable benefits made employees consider changing work position as well (pursuant to $61 \%$ of employees). Unsuitable benefits make employees feel even more dissatisfied than if not provided at all. Preference was given to classical compensation in the form of base pay and bonuses as employees felt that the money earned that could be paid to them had been wasted on benefits that they would not use. Emphasis on financial compensation rather than benefits is a result of the current economic crisis. Overburdening of employees is a problematic phenomenon as well. As revealed by the survey, overtime work is a common practice in the majority of organisations (in $73 \%$ of organisations), which obviously leads to higher dissatisfaction of employees and their inclination to leave. Relationships represent a significant impulse for leaving. One fifth of employees find teams to be inappropriately set up and the determinants motivating teams were also problematic ( $42 \%$ of respondents view their team as demotivating): relationships between management levels and equality in treatment and positions ( $40 \%$ found them unjust and spoke about favouritism). Equal status, recognition and the feeling of participative achievement of goals are of great importance to employees. $28 \%$ of employees expressed an identical opinion that they had not been given any opportunity for development, their work had been monotonous, had not brought any feeling of fulfilment, but rather a feeling of uselessness and stagnation. 57\% of employees had no opportunity of promotion. The impossibility of further development and education led to frustration and a tendency to change the job. More than a quarter of employees did not find they created any value for society, the volume of work available in the organisation did not give them a feeling of security and found the number of processed projects insufficient for future development. The feeling of insecurity aroused tendencies to start seeking a new job that would induce a feeling of stability. Only 53\% of employees thought the way of organisational communications was encouraging, in this context a high percentage (38\%) experienced critique and limitation. Employees characterized communication in organisations as formal (53\%); only $27 \%$ of employees perceived it as informal. This figure is almost alarming if we take into account the fact that $63 \%$ of employees established friendly relations with their colleagues. Almost all other communication was of a formal nature. $24 \%$ of employees found communication techniques extremely unsuitable. Insufficient sharing of information or no sharing is a common reality for $41 \%$ of organisations. The finding that $80 \%$ of employees, as suggested by the addition of previous attributes of dissatisfaction, did not find their current job to be ideal and were in search for a different position is alarming. 
As personnel theory states it is necessary to take into account the needs of employees at different levels of development. The needs that are often overlooked and problematic are the needs of solidarity, friendship, safety and security, fulfilment, recognition by a team and self-fulfilment. The perceived difference between the desired and real situation causes dissatisfaction and employees tend to leave their job. Employees need to be encouraged to perform their tasks in order to increase their feeling of importance, satisfaction, usefulness for the organization and in particular to maintain and increase the overall performance of the organization and productivity of work at the time of economic crisis.

\section{References}

1. Anderson, V. (2009). Research Methods in Human Resource Management. London: Chartered Institute of Personnel Development.

2. Armstrong, M. (2009). Armstrong's handbook of buman resource management practice. London: Kogan Page.

3. Benet-Martinez, V., \& John, O. P. (1998). Los Cinco Grandes across cultures and ethnic groups: Multitrait multimethod analyses of the Big Five in Spanish and English. Journal of Personality and Social Psychology, 75 (3), 729-750. http://dx.doi.org/10.1037/0022-3514.75.3.729

4. Bělohlávek, F. (2008). Jak vést a motivovat lidi. Brno: Computer Press.

5. Bowes, B. J. (2010). A Competitive Employee Market Compels Companies to Manage High Turnover. Retrieved from: http://legacybowesgroup.com/component/content/article/43-retention/183-a-competitive-employee-market-compels-companies-to-manage-high-turnover. html.

6. Branham, L. (2005). The 7 bidden reasons employees leave. New York: AMACOM.

7. Branham, L. (2000). Keeping the people who keep you in business: 24 Ways to Hang on to Your Most Valuable Talent. USA: AMACOM.

8. CIPD - Chartered Institute of Personnel and Development. (2004). Fluktuace a retence zaměstnancü. Retrieved from: http://www.personalista.cz/index.php?ID=33\&basket=b78c3e 42f202e5f773f9fa5074e52209.

9. Deiblová, M. (2005). Motivace jako nástroj rízenení. Praha: Linde.

10. Disman, M. (2008). Jak se vyrábí sociologická ₹nalost. Praha: Karolinum.

11. Ertl, J. (2005). Fluktuace - diagnóza a lécba. Retrieved from: http://www.personall.cz/Fluktuace_I.html.

12. Finnegan, D. (2010). Rethinking Retention. New York: Book Excerpt.

13. Gosling, S. D., Rentfrow, P. J., \& Swann W. B. (2003). A very brief measure of the BigFive personality domains. Journal of Research in Personality, 37 (6), 504-528. http://dx.doi. org/10.1016/S0092-6566(03)00046-1

14. Hackman, J. R. (1980). Work redesign and motivation. Professional Psychology, 11 (3), 445-455. http://dx.doi.org/10.1037//0735-7028.11.3.445

15. Hayes, N. (1998). Základy sociálni psychologie. Praha: Portál.

16. Heathfield, S. M. (2010). More Tips to Reduce Employee Turnover: You Can Reduce Employee Turnover. Retrieved from: http://humanresources.about.com/od/retention/a/turnover_tips.htm. 
17. Horalíková, M., \& Zuzák, R. (2005). Talenty v podnikové praxi. Praha: Credit.

18. Jenkins, A. K. (2009). Keeping the talent: understanding the needs of engineering and scientists in the defense acquisition workforce. Defense A R Journal, 4 (1), 164-170.

19. John, O. P., Naumann, L. P., \& Soto, C. J. (2008). Paradigm Shift to the Integrative BigFive Trait Taxonomy: History, Measurement, and Conceptual Issues. Handbook of personality: Theory and research. New York: Guilford Press.

20. Katcher, B. L., \& Snyder, A. (2007). 30 reasons employees hate thein managers. New York: AMACOM.

21. Kocianová, R. (2010). Personální cinnosti a metody personální práce. Praha: Grada.

22. Maslow, A. (1943). A theory of human motivation. Psychological Review, 50 (4), 370-396. http://dx.doi.org/10.1037/h0054346

23. McClelland, D. C. (1987). Human Motivation. New York: Press Syndicate of the University of Cambridge.

24. McGregor, D. (2006). The Human Side of Enterprise. New York: McGraw-Hill.

25. Meyer, J.P., \& Allen, N.J. (1991). A three-component conceptualization of organizational commitment. Human Resource Management Review, 1 (1), 61-89. http://dx.doi. org/10.1016/1053-4822(91)90011-Z

26. Mikuláštík, M. (2007). Manažerské psychologie. Praha: Grada Publishing.

27. Pass, S. (2005). What's the best way to secure high-performance working and best practice? People Management Magazine. Retrieved from: http://www.peoplemanagement.co.uk/pm/articles/2005/09/ontheline.htm.

28. Pauknerová, D. (2006). Psychologie pro ekonomy a manažery. Praha: Grada.

29. Ramlall, S. (2004). A Review of Employee Motivation Theories and their Implications for Employee Retention within Organizations. The Journal of American Academy of Business, Cambridge, 5 (1/2), 52-63.

30. Reiß, C. (2008). Fluktuation. Retrieved from: http://www.personaleronline.de/typo3/nc/ personalthemen/suche-in-artikeln/detailansicht/artikel/fluktuation.html.

31. Vroom, V. H. (1990). Manage people, not personnel: motivation and performance appraisal. Boston: Harward Business Review.

32. Zahorsky, D. (2010). Fighting Employee Turnover Costs : Reduce Employee Turnover. Retrieved from: http://sbinformation.about.com/od/hiringfiring/a/reduceturnover.htm.

\section{Contact information:}

Ing. Lucie Vnoučková, Ph.D.

Vysoká šoola ekonomie a managementu

Katedra managementu

Nárožni 2600/9a, 15800 Praha 5

e-mail:lucie.vnouckova@vsem.cz.

JEL Classification: J63 